\title{
Irrigation and Mulch Effects
}

\section{on Desert Shrub Transplant Establishment}

\author{
David Bainbridge, John Tiszler, Robert MacAller, and Michael F Allen
}

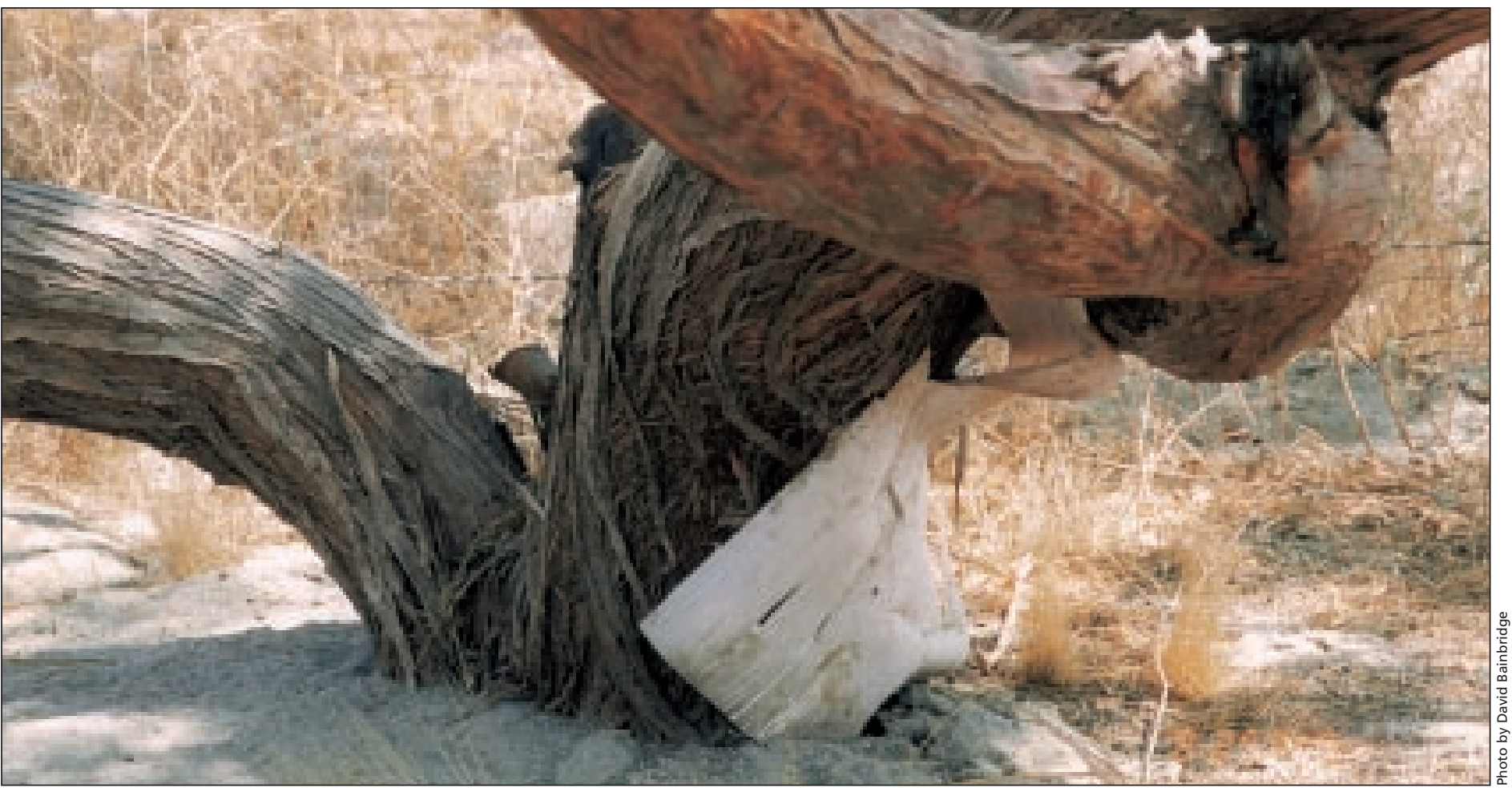

A 7-y-old honey mesquite (Prosopis glandulosa) shows the growth potential of this species on arid Sonoran Desert sites. Note the remnants of the 10 $\mathrm{cm}$ (4 in) diameter Supertube tree shelter.

\section{A B STRACT:}

On a Sonoran Desert site, transplanted honey mesquite (Prosopis glandulosa Torrey var. torreyana (L. Benson) M.C. Johnston [Fabaceae]) seedlings watered through deep-pipes had significantly higher survival (71\%) than those irrigated through buried clay pots $(52 \%)$, and $3 \mathrm{X}$ better survival than surface irrigated (control) plants (23\%). Mesquite watered with deep-pipes were much taller than surface-watered plants. When combined with irrigation, neither bark mulch or vertical mulch of plant stems improved survival and growth. If protected from herbivores, honey mesquite can be successfully established on dry desert sites without mulch using deep-pipe irrigation and minimal water $(<201$ ( 5.3 gal $)$ over 3.5 y).
KEY WORDS: Irrigation efficiency, deep-pipe, clay pot, irrigation, mesquite, Prosopis glandulosa

NOMENCLATURE: ITIS (2000)

upplemental water is usually needed for successful shrub and tree establishment in arid lands, but limited water supplies limit irrigation, and this water is expensive. This makes plant establishment costly and challenging. The United Nations Environment Program estimates that 3.3 billion ha (8.2 billion ac) of degraded land are in need of revegetation worldwide, so improving transplant establish- 


\begin{tabular}{|c|c|c|c|}
\hline \multicolumn{4}{|c|}{ TABLE 1} \\
\hline \multicolumn{4}{|c|}{ Irrigation effects on mesquite transplant survival and growth } \\
\hline Irrigation method & $\begin{array}{c}\text { Survival } \\
\text { (\%) }\end{array}$ & $\begin{array}{l}\text { Mean height } \\
\quad(\mathrm{cm})\end{array}$ & Rating ${ }^{a}$ \\
\hline Deep-pipe & $71 \mathrm{a}$ & 55 a & $3.5 \mathrm{a}$ \\
\hline Clay pot & $52 \mathrm{~b}$ & $32 \mathrm{~b}$ & $2.9 \mathrm{~b}$ \\
\hline Surface & $23 c$ & $30 \mathrm{~b}$ & $2.7 \mathrm{~b}$ \\
\hline$P$ value & 0.001 & 0.03 & 0.004 \\
\hline \multicolumn{4}{|c|}{$\begin{array}{l}1=\text { barely alive, some green on stem, still flexible; } 2=\text { some green on stem, a few } \\
\text { green leaves; } 3=\text { green stem and a number of green leaves; } 4=\text { green stem and } \\
\text { green leaves, vigorous. }\end{array}$} \\
\hline
\end{tabular}

ground can funnel precipitation to subsurface soils (Bainbridge 1996).

Our study objective was to compare the effectiveness of deep-pipe, clay pot and conventional surface irrigation (control) on survival and growth of honey mesquite (Prosopis glandulosa Torrey var. torreyana (L. Benson) M.C. Johnston [Fabaceae]) at a degraded Sonoran Desert mitigation site (Bainbridge and Virginia 1991). We combined this study of irrigation methods with a test of horizontally spread and vertically placed soil surface mulches. Our goal was to develop improved meth-

ment at reduced cost is critical (Lean and Hinrichsen 1994). Modern agricultural irrigation practices such as drip irrigation are not transferable to most degraded arid lands so alternative low technology approaches are needed. Deep-pipe and buried clay pot irrigation are both simple, low cost techniques for improving irrigation delivery and efficiency (Bainbridge and Virginia 1990). Both allow rapid irrigation with little water loss to surface evaporation.

Deep-pipe irrigation supplies water directly to a plant's lower root zone through an open vertical pipe (Mathew 1987). The base of the open pipe is set in the root zone, while the open top extends above ground making it easy to fill the pipe (Bainbridge and Virginia 1990). This method is particularly effective on sloping ground where conventional irrigation often fails to water the intended shrubs, and instead causes erosion as it runs off. A screened cap is used to keep lizards and small animals from falling or crawling into the pipe.

Buried unglazed clay pots also introduce water directly into subsurface soils through capillary action, but not as deeply as the deep-pipe system. Unglazed low-fire clay pots are set into the soil and filled with water. Water seeps through the pores in the clay walls and is made available to nearby plants in a time release fashion (Sheng Han 1974;

Bainbridge and others 1998). This system is selfregulating, as water demand increases so does water delivery (Bainbridge 2000). A cover is placed over the pot to reduce evaporation.

Surface mulches have been used to improve soil infiltration and water retention, reduce soil temperature, and reduce wind velocity at the soil surface in arid lands (Kay 1978; Jalota and Prihar 1998). Surface mulches improve water penetration by impeding runoff and protecting the soil from raindrop impacts and thereby reduce soil crusting (Munshower 1994). Bark mulches have improved survival on arid sites (Zink and Allen 1998). Vertical mulches pushed, or crimped, into the ods of establishing plants on degraded desert sites with minimal water and at minimal cost.

\section{MATERIALS AND METHODS}

The study was conducted in an abandoned highway department borrow pit at the southwest corner of the intersection of Highways 86 and 78, near lower San Felipe Creek in the Sonoran Desert in the Imperial Valley east of San Diego, California. This desert site, located below sea level, is among the hottest in the US and temperatures may exceed $40^{\circ} \mathrm{C}\left[100^{\circ} \mathrm{F}\right]$ any month of the year. Annual rainfall averages only $65 \mathrm{~mm}$ (2.6 in) per year (NOAA 1999; data for Brawley, California), with nearly equal maxima occurring in January, from winter frontal storms from the Pacific, and in August, from summer storms moving north from the Gulf of California. This is an exposed site with high winds common at very low relative humidity (< $10 \%)$, particularly in spring.

The surrounding area is degraded Sonoran desert creosote (Larrea tridentata (Sessé \& Moc. ex DC.) Coville [Zygophllaceae] scrub with occasional mesquite mounds, where shrubs have captured blowing sands and created captured dunes or nebkas (Le Houérou 1986). The site had several feet of soil removed and the remaining consolidated lacustrine soils are fine sand with considerable clay.

We used a 3 irrigation X 3 mulch factorial design creating 9 irrigation-mulch treatments (described below). Replicate treatments were organized into eight 5-m X 5-m [16.4-ft X 16.4-ft] blocks with each treatment combination represented in each block. Within blocks, treatments were randomly assigned to $1-\mathrm{m}^{2}\left[10.8 \mathrm{ft}^{2}\right]$ plots spaced $1 \mathrm{~m}[3.3 \mathrm{ft}]$ apart.

\section{Irrigation Treatments}

Deep-pipe irrigation: PVC pipes (5-cm (2-in) diameter, $100-\mathrm{cm}$ (40-in) length) were placed vertically in the ground in holes drilled with a hand 


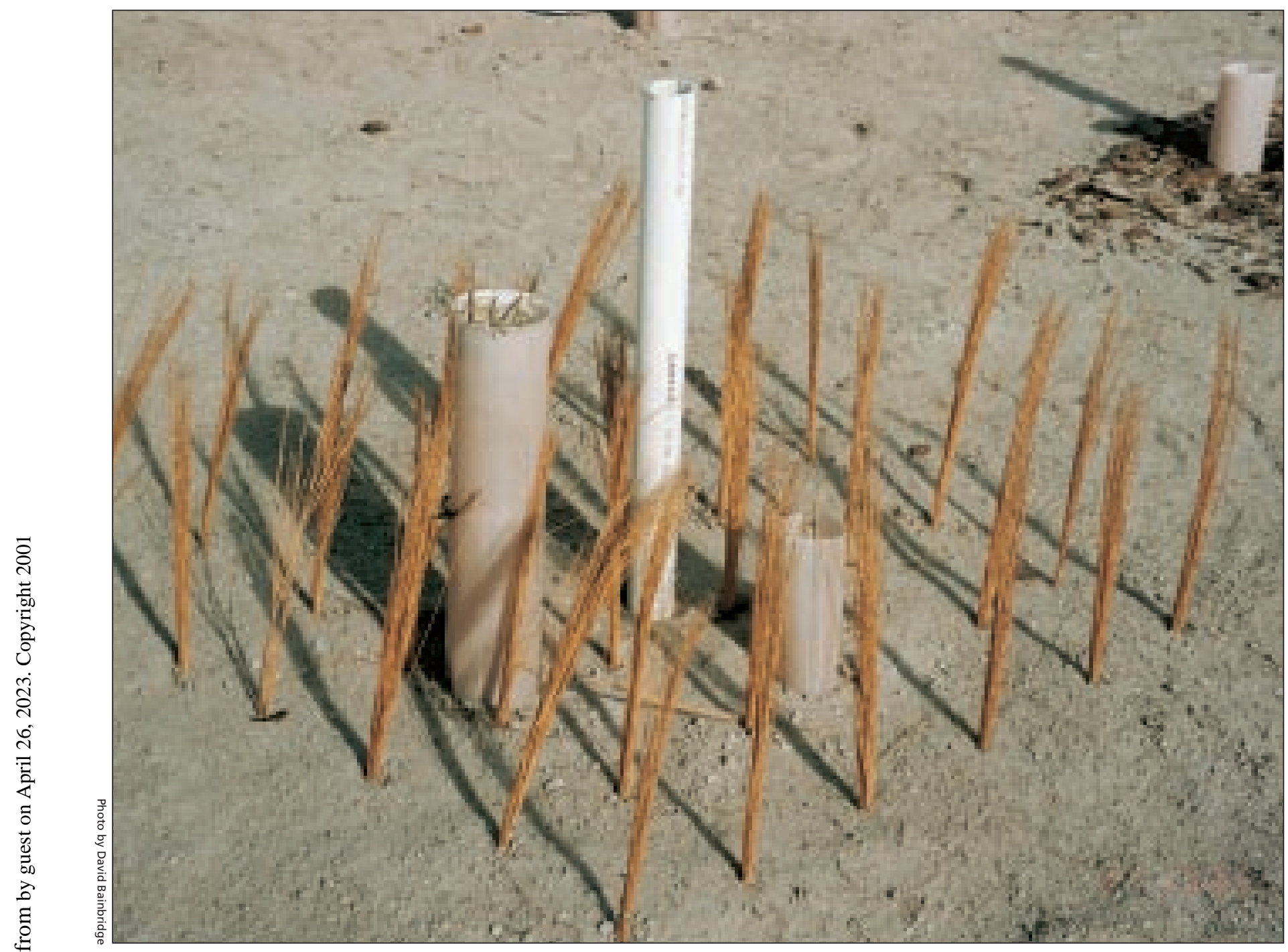

Figure 1 - A plot with deep-pipe irrigation, mulched with dried broom corn sprigs, with seedlings in tree shelters.

auger (Figure 1). The open base of each pipe was $50 \mathrm{~cm}$ (20 in) deep and the total volume of the pipe was 21 (0.5 gal).

Buried clay pot irrigation: Unglazed, lowfired $20-\mathrm{cm}$ (8-in) diameter clay pots (red clay garden pots) with drainage holes sealed with silicone caulk were buried with the lip of each pot flush to the ground surface. Pots had a volume of 2.41 (0.6 gal) and were covered with an aluminum cover. The cover had several holes punched to allow rainwater entry and was weighted with rock attached with glue.

Surface watering (control): Without first creating a berm or basin, water was poured onto the soil around the plant. From our earlier trials in this region, we knew survival without irrigation would be $<1 \%$ so a conventional "no water" control was omitted.

\section{Mulch Treatments}

Surface mulch: Medium-sized pine bark chips (1 to 3 -cm [0.4 to 1.2 -in]) were spread over plots to create a continuous 2-cm-deep (0.75-in) mulch layer.

Vertical mulch: Dried broom corn sprigs (Sorghum vulgare) were inserted into the soil in a grid at $20-\mathrm{cm}(8$-in) intervals, with 25 sprigs per $\mathrm{m}^{2}\left(10.8 / \mathrm{ft}^{2}\right)$. The broom corn stems were buried 10 to $15-\mathrm{cm}$ ( 4 to 6 in) deep with the exposed portion standing 45-cm (18-in) vertically (Figure 1).

Bare ground (control).

\section{Planting, Irrigating, and Rating}

On 16 November 1995, we planted each plot with two 20-cm-tall (8-in) mesquite seedlings grown in $330-\mathrm{cm}^{3}\left(20-\mathrm{in}^{3}\right)$ plant bands (for a discussion of techniques see Bainbridge 1994b; Bainbridge and others 1995). Seedlings were placed within $10 \mathrm{~cm}$ 
(4 in) and on opposite sides of the deep-pipe or clay pots which were centered in the mulch plots. Plants were placed $10 \mathrm{~cm}$ (4 in) from the surface watering plot midpoints.

A total of 144 mesquite were planted and enclosed in 10-cm (4-in) diameter Supertube ${ }^{\circledast}$ tree shelters that have been found to improve plant survival in arid environments (Bainbridge 1994a; Grantz and others 1998). Tree shelters were used on all plants because previous studies (unpublished) in this area have demonstrated that herbivory would soon eliminate all unprotected transplants. One plant in each treatment received a $30-\mathrm{cm}$ (12-in) and the other a $15-\mathrm{cm}(6-\mathrm{in})$ tree shelter, due to supply limitations (Figure 1).

Each treatment received the same amount of water over the course of the experiment. We watered each plant with a liter $(0.26 \mathrm{gal})$ of water every $2 \mathrm{wk}$ for $8 \mathrm{wk}$, applied directly into the tree shelter. Then irrigation treatments were begun and each treatment received 2.41 ( $0.6 \mathrm{gal})$ of water (1.2 l (0.3 gal) per plant) every other week for 3 mo. Deep-pipes were over-filled, the clay pots were filled, and the surface irrigation was applied evenly to the entire surface of the plot. Intervals between irrigation were then increased to once a month for 4 mo, ending in mid-July. Plots received 2.41 (0.6 gal) once in 1997 and once in 1998. Total water application was < 201 ( $5.3 \mathrm{gal})$ per plant over $3.5 \mathrm{y}$.

The final monitoring for overall seedling vigor was done on 21 June 1999 using this qualitative index: 1 = barely alive, some green on stem, still flexible; 2 = some green on stem, a few green leaves; 3 = green stem and a number of green leaves; $4=$ green stem and green leaves, vigorous.

After 3.5 y the results were analyzed using an analysis of variance with a $95 \%$ confidence level. When results were found to be significant a Fisher's protected least squares difference was used to analyze significant differences between treatments.

\section{RESULTS AND DISCUSSION}

All seedlings survived the first winter and plant growth was rapid. The experimental site experienced a drought during the study. Rainfall during the course of this experiment was estimated from nearby weather station records (Ocotillo Wells, California, data from OWSVRA (1999); Brawley and Seeley, California, data from CIMIS [1999]). Rainfall from September 1995 to June 1996 was only $3 \mathrm{~mm}$ (0.11 in); $16.5 \mathrm{~mm}$ (0.65 in) fell from June 1996 to May 1997; $107 \mathrm{~mm}$ (4.2 in) fell from June 1997 to May 1998; and from June 1998 to May $19998.6 \mathrm{~mm}$ (0.34 in). Average annual rainfall over the course of this study was $31 \mathrm{~mm}$ (1.3 in). Evapotranspiration determined at a nearby site was $1940 \mathrm{~mm}$ (76.4 in) during the 1998-1999 season (CIMIS 1999).
The height data is partially confounded by severe herbivory by black-tailed jack rabbits (Lepus californicus Gray [Leporidae]). Intense browsing limited growth to the top of the tree shelters during the worst periods, although eventually a few trees escaped and grew as the drought reduced rabbit populations. Herbivory was consistent throughout the plots and height comparison data reflect plant resilience, not differential browsing. Mulch treatments were still intact and functional at the final monitoring. As irrigation was discontinued the survival gradually declined, but now appears to have stabilized, with overall survival at $49 \%$. The survival by irrigation treatment, mean height, and health ranking after $3.5 \mathrm{y}$ are shown in Table 1. Significant differences or trends in survival or height based on mulch treatment were absent. Analysis of the mulch $\mathrm{X}$ irrigation interaction also showed no statistically significant differences.

Benefits of deep-pipe irrigation were clearly confirmed in this experiment and this method of irrigating plants in arid environments should be more widely used. Survival of plants on deep-pipe systems was much better than that with clay pots and $3 \mathrm{X}$ that found with surface irrigation. The deep-pipe system also developed resilient plants that were able to grow taller than the treeshelters despite severe herbivory. This suggests, as noted by Mathew (1987), that more extensive root systems had developed. Nine of the ten biggest plants, with heights ranging from 87 to $210 \mathrm{~cm}$ (34 to 83 in), were on deep-pipe systems. The benefits of clay pot irrigation were less than expected, perhaps because inexperienced field crews placed the seedlings too far, $10 \mathrm{~cm}$ ( $4 \mathrm{in}$ ), from the pots to benefit fully from the irrigation water. In other cases clay pot irrigation has proved to be very effective in arid environments (Shiek'h and Shah 1983; Bainbridge and Virginia 1990; Bainbridge 2000).

The use of mulch to improve seedling establishment in very arid environments was not supported by our study, although it has been very effective in other cases (Bainbridge 1996; Minhas and Gil 1985; Jalota and Prihar 1998). We have seen benefits from mulch when sufficient rain fell to cause surface ponding and sheet flow, but it is likely this condition occurred rarely, if at all, during the course of this study. It appears that the use of mulch, like many other arid zone techniques, is a gamble. It helps if rains are heavy, it hurts if rains are light. Jalota and Prihar (1998) reviewed the effects of mulch on soil moisture content and found that mulch may be of little value or even detrimental in low rainfall periods because the mulch can intercept moisture from light rains before it reaches the soil. Mulch can also wick moisture from the soil into the air, increasing evap- 
oration. In their own experiments, Jalota and Prihar (1990) determined that with evaporation rates of $15.4 \mathrm{~mm}$ (0.61 in) per day (common at this site) unmulched soil conserved more moisture than mulched soil.

Despite severe herbivory and limited rainfall more than $70 \%$ of the mesquite seedlings started on deep-pipe irrigation were still alive after $3.5 \mathrm{y}$. The general recommendation from our study would be to: 1) use deep-pipe irrigation to establish shrubs and trees in very arid environments; and 2) avoid the use of surface or vertical organic mulch. Without intervention it may take centuries for degraded sites to recover in these arid environments (Webb and others 1983), yet this study suggests that with minimal water even arid sites can be revegetated. Desert revegetation is not easy or inexpensive, but it can be done.

\section{REFERENCES}

Bainbridge DA. 1994a. Treeshelters improve establishment on dry sites. Tree Planters' Notes 45(1):13-16.

Bainbridge DA. 1994b. Container optimization: field data support innovation. In: Landis TD, Dumroese RK, technical coordinators. National proceedings, forest and conservation nursery associations. Fort Collins (CO): USDA Forest Service, Rocky Mountain Forest and Range Experiment Station. General Technical Report RM-257. p 99-104.

Bainbridge DA. 1996. Vertical mulch. Restoration and Management Notes 14(1):72.

Bainbridge DA. 2000. Buried clay pot irrigation. Agricultural Water Management: forthcoming.

Bainbridge DA, Virginia RA. 1990. Restoration in the Sonoran desert. Restoration and Management Notes 8(1):3-14.

Bainbridge DA, Virginia RA. 1991. Honey mesquite: a multipurpose tree for arid lands. Nitrogen Fixing Tree Association. NFT Highlights 90-07. 2 p.

Bainbridge DA, Fidelibus M, MacAller R. 1995. Techniques for plant establishment in arid ecosystems. Restoration and Management Notes 13(2):198-202.

Bainbridge DA, Steen W, Steen A. 1998. Super-efficient irrigation with buried clay pots. San Diego (CA): United States International University, Environmental Studies Program. Canelo Project. 5 p.

[CIMIS] California Irrigation Management Information System. 1999. California Department of Water Resources DPLA. URL: http//:wwwdpla.water.ca. gov/cgi-bin/cimis/cimis/data (accessed 21 Dec 1999).

Grantz D, Vaughn D, Farber R, Kim B, Ashburger L, VanCuren T, Campbell R, Bainbridge DA, Zink TA. 1998. Transplanting native plants to revegetate abandoned farmland in the western Mojave Desert. Journal of Environmental Quality 27(4):960-967.

[ITIS] Integrated Taxonomic Information System. 2000. Biological names. Version 4.0 [on-line database]. URL: http://www.itis.usda.gov/plantproj/itis/itis-query.html (accessed 31 Oct 2000).

Jalota SK, Prihar SS. 1990. Effect of straw mulch on evaporation reduction in relation to rates of mulching and evaporativity. Journal of the Indian Society of Soil Science 38:728-730.

Jalota, SK, Prihar SS. 1998. Reducing soil water evaporation with tillage and mulching. Ames (IA): lowa State University Press. $142 \mathrm{p}$.

Kay BL. 1978. Mulch and chemical stabilizers for land reclamation in dry regions. In: Schaller FW, Sutten P, editors. Reclamation of drastically disturbed lands. Madison (WI): American Society of Agronomy. p 467-483.

Lean G, Hinrichsen D. 1994. Atlas of the environment. New York (NY): Harper-Collins. p 53-56.
Le Houérou HN. 1986. The desert and arid zones of northern Africa. In: Evenari M, Noy-Meir I, Goodall, DW, editors. Hot deserts and arid shrublands. Elsevier, Amsterdam. p 101$147 \mathrm{M}$.

Mathew TJ. 1987. Cheap micro-irrigation by plastic pipes. In: Simple methods of localized water conservation. Areeplachy, Kerala, India: Indian Society for Soil and Water Conservation. p 22.

Minhas PS, Gil AS. 1985. Evaporation from soil as affected by incorporation and surface and subsurface placement of oat straw. Journal of the Indian Society of Soil Science 33:774-778.

Munshower FF. 1994. Practical handbook of disturbed land revegetation. Boca Raton (FL): Lewis Publishers. p 85.

[NOAA] National Oceanic and Atmospheric Administration. 1999. NNDC climate data online. URL: http://www5.ncdc. noaa.gov:7777/plclimprod/ plsq/poemain.poe (accessed 21 Dec 1999).

[OWSVRA] Ocotillo Wells State Vehicular Recreation Area, California. 1999. Personal communication.

Sheng Han S. 1974. Fan Sheng-chih Shu: an agriculturist book of China written by Fan Sheng-chih in the first century BC. Peking, China: Science Books. p 36-37.

Shiek'h MT, Shah BH. 1983. Establishment of vegetation with pitcher irrigation. Pakistan Journal of Forestry 33(2):75-81.

Webb RA, Wilshire HG, Henry MA. 1983. Natural recovery of soils and vegetation following human disturbance. In: Webb RA, Wilshire RG, editors. Environmental effects of off-road vehicles. New York (NY): Springer-Verlag. p 279-302.

Zink TA, Allen MF. 1998. The effects of organic amendments on the restoration of a disturbed coastal sage scrub habitat. Restoration Ecology 6(1):52-58.

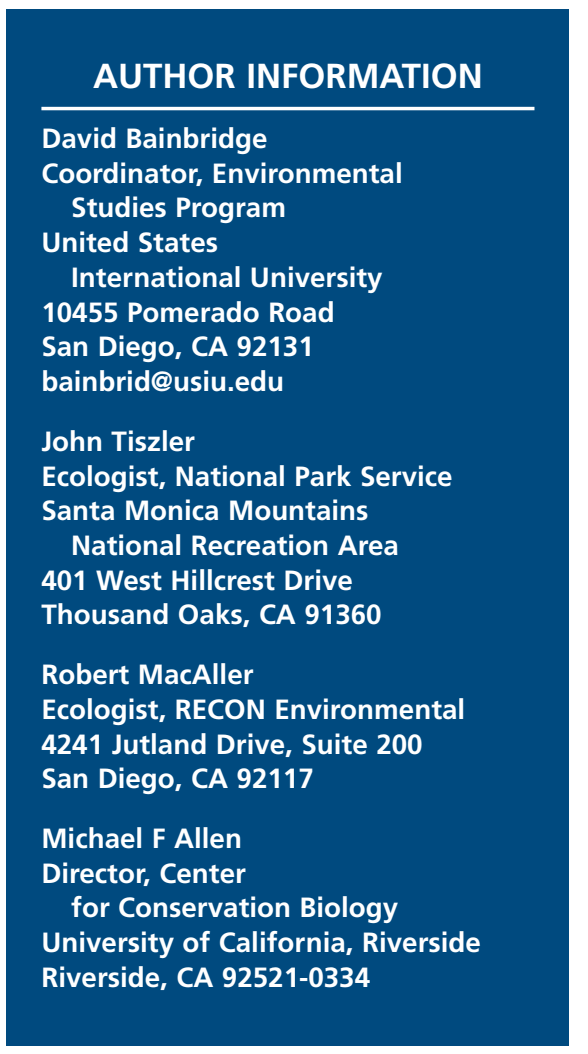

